\title{
ASSESSMENT OF PCR IN THE DETECTION OF Leishmania spp IN EXPERIMENTALLY INFECTED INDIVIDUAL PHLEBOTOMINE SANDFLIES (DIPTERA: PSYCHODIDAE: PHLEBOTOMINAE)
}

\author{
Érika M. MICHALSKY(1), Consuelo L. FORTES-DIAS(2), Paulo F.P. PIMENTA(3), Nágila F.C. SECUNDINO(3) \& Edelberto S. DIAS(1)
}

\begin{abstract}
SUMMARY
DNA amplification by the polymerase chain reaction (PCR) was applied in the investigation of the presence of Leishmania (Kinetoplastida: Trypanosomatidae) parasites in single phlebotomine sandflies. Three phlebotomine/parasite pairs were used: Lutzomyia longipalpis/Leishmania chagasi, Lutzomyia migonei/Leishmania amazonensis and Lutzomyia migonei/Leishmania braziliensis, all of them incriminated in the transmission of visceral or cutaneous leishmaniasis. DNA extraction was performed with whole insects, with no need of previous digestive tract dissection or pooling specimens. The presence of either mouse blood in the digestive tract of the sandflies or the digestive tract itself did not interfere in the PCR. Infection by as few as 10 Leishmania sp. per individual were sufficient for DNA amplification with genus-specific primers. Using primers for L. braziliensis and L. mexicana complexes, respectively, it was possible to discriminate between L. braziliensis and L. amazonensis in experimentally infected vectors (L. migonei).
\end{abstract}

KEYWORDS: Lutzomyia; Leishmania; PCR; Leishmaniasis.

\section{INTRODUCTION}

Leishmaniasis are a group of enzootic and zoonotic diseases caused by protozoan parasites of the genus Leishmania (Kinetoplastida:Trypanosomatidae) displaying varying degrees of specificity for the host ${ }^{5}$. They are widely distributed in the American continent from the United States to Northern Argentina, under two distinct clinical forms: visceral and cutaneous. The transmission of leishmaniasis occurs upon biting by several species of phlebotomine vectors, whose source of infection comprises different mammal species.

In Brazil, Lutzomyia longipalpis is the natural vector of Leishmania chagasi, agent of visceral leishmaniasis. On the other hand, the cutaneous form of leishmaniasis can be caused by several Leishmania species; among them Leishmania braziliensis and Leishmania amazonensis, belonging to L. braziliensis and L. mexicana complexes, respectively, are the most well known. L. braziliensis is spread over several Brazilian regions, whereas L. amazonensis was described in the northern South America. Both species of Leishmania may infect Lutzomyia migonei ${ }^{4}$.

The rate of naturally infected sandflies in endemic areas and the correct identification of the infecting Leishmania in a determined phlebotomine species are of prime importance in vectorial and epidemiological studies of leishmaniasis. The most commonly used method for that investigation is the laborious and time-consuming search for the parasite in loco, after dissection of the digestive tract of the insect.
Besides, in putative positive cases, the infection has to be confirmed by in vitro culture of the Leishmania, often susceptible to contamination, or by inoculation into laboratory animals, as other non-identified flagellates are commonly found in the digestive tract of those insects ${ }^{13,15}$.

In the last ten years, molecular methods have been developed for the identification of certain species of Leishmania, either isolated from cultures or from patients ${ }^{13}$ as well as in the detection of the parasite in a pool of phlebotomine specimens ${ }^{14}$. The main advantages of these methods are their sensitivity and specificity, independently of the number, stage and localization of the Leishmania in the digestive tract of the vector ${ }^{10}$. In the last few years, it has been successfully applied to field studies on the vectorial competence of phlebotomine sandflies ${ }^{1,12}$, even in areas with low rates of infection ${ }^{9,14}$.

Our aim in the present study was to assess the use of PCR in the detection of Leishmania sp. in individual sandflies (L. longipalpis and L. chagasi) experimentally infected, using the whole insect for the DNA extraction, without any dissection step. The specificity of the method was also tested after infection of $L$. migonei with $L$. braziliensis and $L$. amazonensis, to which complex-specific primers are available ${ }^{6,8}$.

\section{MATERIAL AND METHODS}

Leishmania parasites - Strains of L. chagasi (MHOM/BR/74/PP/ 75), L. braziliensis (MHOM/BR/75/M2903) and L. amazonensis (IPLA/

(1) Laboratório de Leishmanioses, Centro de Pesquisas René Rachou, Fundação Oswaldo Cruz, Belo Horizonte, MG, Brasil.

(2) Laboratório de Biologia Molecular, Centro de Pesquisa e Desenvolvimento, Fundação Ezequiel Dias, Belo Horizonte, MG, Brasil

(3) Laboratório de Entomologia Médica, Centro de Pesquisas René Rachou, Fundação Oswaldo Cruz, Belo Horizonte, MG, Brasil.

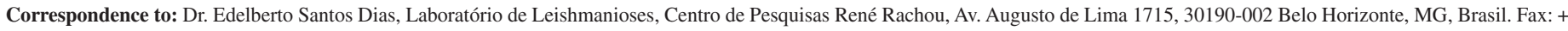
5531329531 15. e-mail: edel@cpqrr.fiocruz.br 


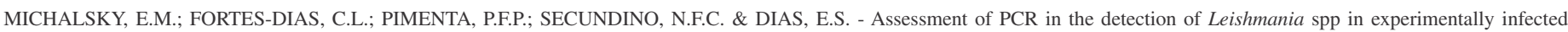
individual phlebotomine sandflies (Diptera: Psychodidae: Phlebotominae). Rev. Inst. Med. trop. S. Paulo, 44(5):255-259, 2002.

BR/67/PH8) were cultured in M199 medium containing 5\% fetal calf serum. L. chagasi amastigotes were obtained by in vitro transformation ${ }^{2}$ whereas the other two strains were periodically inoculated into the rear paw of hamster (Mesocricetus auratus).

Assay sensitivity - 3- to 4-day-old laboratory reared females of $L$. longipalpis were dissected and to their digestive tracts were added serial dilutions of $L$. chagasi from in vitro cultures, containing 10, 100 or 1,000 promastigotes in $10 \mu \mathrm{l}$ of PBS, followed by $10 \mu \mathrm{l}$ of PBS or mouse blood. Controls containing L. chagasi culture dilutions only were prepared.

Blind assay - 3- to 4-day-old laboratory reared females of $L$. longipalpis were dissected and to their digestive tracts were added or not $10 \mu \mathrm{l}$ of $L$. chagasi cultures. After codified identification, twenty samples were submitted to DNA extraction and amplification with genusspecific primers, as described.

Experimental infection - Groups of 130 4-day-old laboratory-reared females of L. longipalpis were experimentally infected by artificial feeding ${ }^{15}$ on heparinized mouse blood, containing $2 \times 10^{7}$ parasites $/ \mathrm{ml}$ of $L$. chagasi. The same procedure was used for infection of $L$. migonei with either L. amazonensis or L. braziliensis. Individual test samples were prepared with whole insects, without any dissection, 7 days after the artificial feeding, as follows: 1- Thirty samples of L. longipalpis after meal on blood infected with $L$. chagasi; $2-$ Thirty samples of $L$. migonei after meal on blood infected with L. braziliensis; 3- Thirty samples of L. migonei after feeding on blood infected with $L$. amazonensis. All samples were stored in $10 \mu \mathrm{l}$ of PBS at $-80{ }^{\circ} \mathrm{C}$. Each sample was submitted to DNA extraction and amplification, as described.

DNA extraction - DNA was extracted by maceration in a microtube using a plastic pestle, followed by addition of $35 \mu$ of lysis buffer (100 $\mathrm{mM}$ TRIS-HCl, $100 \mathrm{mM} \mathrm{NaCl}, 25 \mathrm{mM}$ EDTA, 0.5\% SDS, pH 8.0) and another maceration step. The test samples were digested overnight at $37{ }^{\circ} \mathrm{C}$ by proteinase $\mathrm{K}(1.25 \mu \mathrm{l}$ of a $10 \mathrm{mg} / \mathrm{ml}$ solution $)$ and the DNA extracted by phenol-chloroform ${ }^{3}$. The DNA pellet was ressuspended in $20 \mu \mathrm{l}$ of TE (10 mM TRIS-HCl pH 8.0, $1 \mathrm{mM}$ EDTA). Ten $\mu \mathrm{l}$ were used to estimate the DNA concentration and purity at 280 and $260 \mathrm{~nm}$ in a spectrophotometer, then discarded. The remaining $10 \mu \mathrm{l}$ were stored at $-20{ }^{\circ} \mathrm{C}$ until use.

DNA amplification - Extracted DNA was amplified by hot start PCR in a thermocycler (Perkin-Elmer 2400). The reaction mixture was prepared as follows: $10 \mu \mathrm{l}$ of PCR buffer (100 mM TRIS-HCl, $500 \mathrm{mM} \mathrm{KCl}$, $15 \mathrm{mM} \mathrm{MgCl}$, pH 9.0), $5 \mu \mathrm{l}$ dNTPs ( $2 \mathrm{mM}$ each), $2 \mu \mathrm{l}$ each of primers (200 ng/ $\mu \mathrm{l}), 0.5 \mu \mathrm{l}$ of Taq DNA polymerase $(2.5 \mathrm{U} / \mu \mathrm{l})$ and $26.5 \mu \mathrm{l}$ of ultrapure water. Two $\mu$ l of DNA $(10 \mathrm{ng} / \mu \mathrm{l})$ were added per reaction and DNA amplification was performed as described, using primers previously designed for Leishmania spp.7': 5' GGG GAG GGG CGT TCT GCG AA 3'; 5'CCG CCC CTA TTT TAC ACC AAC CCC 3'; 5' GGC CCA CTA TAT TAC ACC AAC CCC 3'. In the case of amplification with specific primers, B1 (5' GGG GTT GGT GTA ATA TAG TGG 3') and B2 (5' CTA ATT GTG CAC GGG GAG G 3') for L. braziliensis ${ }^{6}$ complex or M1 (5'CCA GTT TCG AGC CCC GGA G3') and M2 (5'GGT GTA AAA TAG GGG CGG ATG CTC TG 3') for $L$. mexican ${ }^{8}$ complex, the following volumes were used: $5 \mu \mathrm{l}$ of PCR buffer, $8 \mu \mathrm{l}$ of dNTPs, $0.5 \mu \mathrm{l}$ of each $\operatorname{primer}(20 \mathrm{pmol} / \mu \mathrm{l}), 2 \mu \mathrm{l}$ of DNA $(10 \mathrm{ng} / \mu \mathrm{l}), 0.5 \mu \mathrm{l}$ de Taq DNA polymerase (2.5 $\mathrm{U} / \mu \mathrm{l})$ and $33.5 \mu \mathrm{l}$ of ultrapure water. DNA amplification was performed for 35 cycles under the temperatures established before ${ }^{6}$. Negative (no DNA) and positive (L. braziliensis or L. amazonensis DNA) controls were used in all experiments.

DNA electrophoresis - $15 \mu \mathrm{l}$ of the amplification products were analysed by $2 \%$ (genus level) or $1 \%$ (complex level) agarose gels (6.4 $\mathrm{cm} \times 10.0 \mathrm{~cm}$ ) in TBE buffer (0.089 M TRIS-HCl, $0.089 \mathrm{M}$ boric acid, $0.02 \mathrm{M}$ EDTA) containing $0.75 \%$ ethidium bromide for $30 \mathrm{~min}$ at 100 $\mathrm{V}$, after addition of orange $\mathrm{G}$ as the tracking dye in the samples. ФX174RF/ HaeIII or pUC19/HpaII DNA fragments were used as size markers. The amplification products were visualyzed under UV light and the gels documented by an Eagle Eye System (Stratagene, La Jolla, USA).

Experimental rates of infection - Seven days after the artificial feeding, 30 specimens per group were dissected and examined microscopically for the presence of Leishmania parasites. Experimental rates of infection per group were determined as the percentage of infected individuals among the total examined.

\section{RESULTS}

Our initial step was to test the sensitivity of the PCR assay by using variable amounts of Leishmania parasites for DNA extraction. In the range tested, the amplified product characteristic of the genus Leishmania (120bp) was observed in samples containing as few as 10 promastigotes (Fig. 1A). Presence of digestive tract of the insect, with or without additon of mamalian blood, did not interfere with the assay (Fig. 1A). Hundred per cent of positivity was observed in the PCR when a blind assay was performed (Table 1).

Using experimentally infected sandflies, DNA amplification with genus-specific primers gave the results shown in Table 2, using whole $L$. longipalpis insects without any dissection step. The 120bp-fragment (Fig. 1B) was present in $87 \%$ of the test samples, respectively. The possibility of false-negative results due to the presence of any inhibitory contamination in the amplification reaction was checked by arbitrary addition of Leishmania DNA and new PCR. All negative results were confirmed (data not shown).

Similar assays using specific primers for L. braziliensis or $L$. mexicana complexes gave $40 \%$ and $36 \%$ positivity for L. migonei, respectively, indicated by the amplification of a 700-800bp fragment in both cases (Fig. 2A and 2B). The percentages of infection were further confirmed by amplification with genus-specific primers for Leishmania.

\section{DISCUSSION}

PCR has been extensively used in molecular diagnosis of human diseases and epidemiological studies due to its high sensitivity ${ }^{11}$. Theoretically, the presence of one parasite per sandfly should be enough to be detected by $\mathrm{PCR}^{6}$. In practice, purified DNA from $5 \mathrm{~L}$. (V.) braziliensis parasites from serially diluted cultures were shown to be the minimum required for amplification ${ }^{13}$. However, this number has not been confirmed when field specimens were used for DNA extraction. The fact was attributed to a probable interference of digestive tract contents of the sandfly ${ }^{1}$. A semi-nested PCR was then developed which was able to detect a minimum of 3 parasites per sandfly ${ }^{1}$. Even though, the need of dissection was emphasized. 


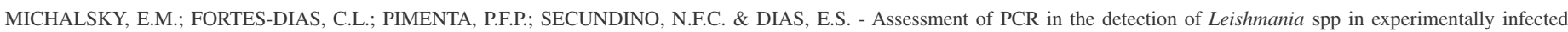
individual phlebotomine sandflies (Diptera: Psychodidae: Phlebotominae). Rev. Inst. Med. trop. S. Paulo, 44(5):255-259, 2002.

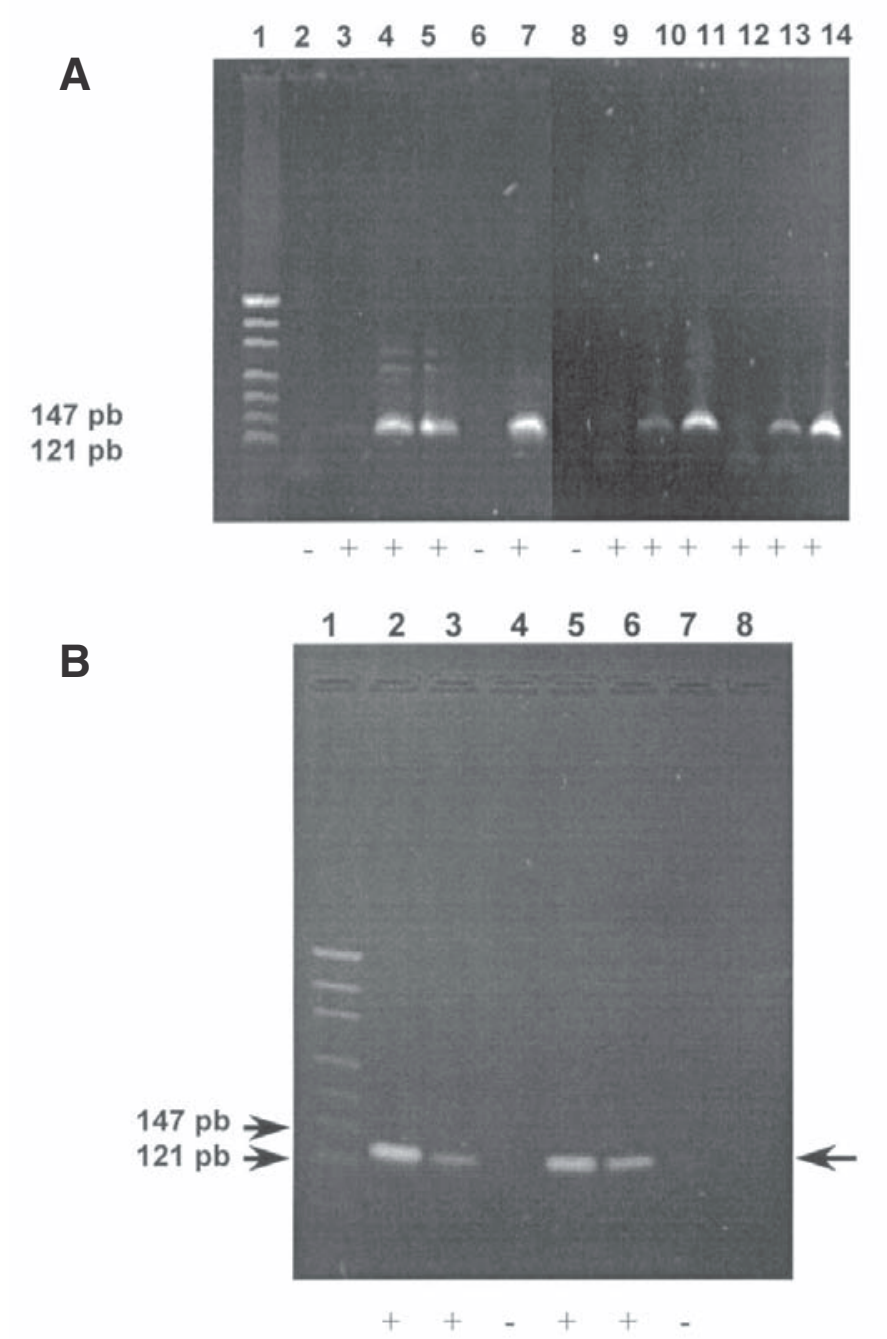

Fig. 1 - Electrophoresis on $2 \%$ agarose gel of PCR products after DNA amplification of test samples with genus-specific primers. A. DNA from cultured Leishmania. 1- pUC19/HpaII DNA marker, 2- Whole mouse blood; 3, 4 and 5- 10, 100 or 1,000 parasites, respectively; 6Negative control; 7- Positive control (L. braziliensis DNA); 8- Digestive tract of L. longipalpis; 9, 10,11-10, 100 or 1,000 parasites, respectively, in the presence of digestive tract of $L$. longipalpis; 12,13,14-10,100 or 1,000 parasites, respectively, in the presence of whole mouse blood and non-infected digestive tract of L. longipalpis. B. DNA from Leishmania infected sandflies. 1- pUC19/Hpa II DNA marker; 2- Positive control (L. braziliensis DNA); 3 to 7 - Test samples in blind assay (dissected digestive tract of L. longipalpis with or without addition of L. chagasi parasites). 8- Negative control. Plus (+) or minus (-) at the bottom of the figures indicate the presence or absence of Leishmania in the test samples.

In our case, using regular PCR, the genus-specific fragment was obtained in the presence of as few as 10 parasites per sandfly when infection was simulated by adding a known number of parasites to the test sample. In a blind assay, the presence of the parasite was confirmed by PCR results in $100 \%$ of cases. The presence of digestive tract of Lutzomyia or any content of it including mouse blood, that could inhibit or interfere in the amplification reaction, did not interfere in the assay or its sensitivity.

Satisfactory results were obtained with whole sandflies, suggesting
Table 1

Detection of PCR products of Leishmania in a blind assay using dissected intestinal tract of Lutzomyia longipalpis in the presence or absence of Leishmania chagasi parasites as test samples*

\begin{tabular}{ccc}
\hline $\begin{array}{c}\text { Sample } \\
\text { identification }\end{array}$ & $\begin{array}{r}\text { Presence of genus-specific } \\
\text { fragment after PCR }\end{array}$ & $\begin{array}{c}\text { Parasite } \\
\text { addition }\end{array}$ \\
\hline 1 & + & Yes \\
2 & - & No \\
3 & + & Yes \\
4 & + & Yes \\
5 & - & No \\
6 & - & No \\
7 & + & Yes \\
8 & + & Yes \\
9 & + & Yes \\
10 & - & No \\
11 & - & No \\
12 & - & No \\
13 & - & No \\
14 & + & Yes \\
15 & + & Yes \\
16 & + & Yes \\
17 & - & No \\
18 & + & Yes \\
19 & + & Yes \\
20 & + & No \\
\hline
\end{tabular}

* Test samples preparation: 3- to 4-day-old laboratory reared females of $L$. longipalpis were dissected and their digestive tracts added or not by $10 \mu 1$ of $L$. chagasi cultures. After codified identification, twenty samples were submitted to DNA extraction and amplification with genus-specific primers, as described under Material and Methods.

no need of dissection or pooling insects for application in field surveys. The percentages of positive samples by PCR, after experimental infection, were similar to the rates of infection determined by insect dissection. In the latter case, rates below $100 \%$ are usually obtained after sandflies feeding on mouse blood due mainly to no feeding at all or a natural failure in the establishment of infection.

Use of PCR for diagnosis of leishmaniasis presents many advantages, among which the possibility of precise identification of the infecting parasite in insect vectors as described here for L. braziliensis ${ }^{6}$ or $L$. amazonensis $^{8}$, as long as appropriate primers are available without need of further hybridization ${ }^{11,13}$. The method is simple and fast enough to be used for screening a large number of insects.

\section{RESUMO}

\section{Avaliação do PCR na investigação de Leishmania spp em flebotomíneos experimentalmente infectados (Diptera: Psychodidae: Phlebotominae)}

Neste trabalho avaliamos o uso da reação em cadeia da polimerase (PCR) na investigação da presença de parasitas Leishmania (Kinetoplastida:Trypanosomatidae) em flebotomíneos individuais. Para isso, foram utilizados três pares flebotomíneo/parasita: Lutzomyia 


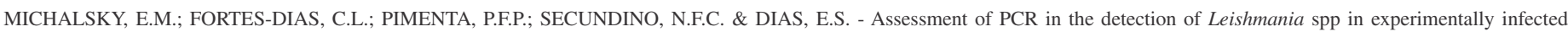
individual phlebotomine sandflies (Diptera: Psychodidae: Phlebotominae). Rev. Inst. Med. trop. S. Paulo, 44(5):255-259, 2002.

Table 2

Comparison of Leishmania spp infection in Lutzomyia spp* by microscopic dissection or whole insect PCR using genus- and complex-specific primers

\begin{tabular}{lccc}
\hline $\begin{array}{l}\text { Phlebotomine } \\
\text { Parasite }\end{array}$ & $\begin{array}{c}\text { L. longipalpis } \\
\text { L. chagasi }\end{array}$ & L. amazonensis & L. braziliensis \\
\hline $\begin{array}{l}\text { Size of amplified } \\
\text { fragments }\end{array}$ & $120 \mathrm{bp}$ & $760 \mathrm{bp}$ & $760 \mathrm{bp}$ \\
\hline $\begin{array}{l}\text { Number of } \\
\text { sandflies } \\
\text { examined }\end{array}$ & 30 & 30 & 30 \\
\hline
\end{tabular}

\section{Rate of}

experimental

infection by

microscopic

examination (\%)

70

40

$50 / 55^{* *}$

Rate of positivity

by PCR $(\%)$

* Groups of 130 laboratory-reared females of L. longipalpis were experimentally infected by artificial feeding on heparinized mouse blood containing $2 \times 10^{7}$ parasites $/ \mathrm{ml}$ of $L$. chagasi. The same procedure was used for infection of $L$. migonei with either L. amazonensis or L. braziliensis. Thirty specimens per group were submitted to DNA extraction and amplification for determination of the rate of positivity by PCR. The experimental rates of infection were determined as the percentage of infected individuals among 30 microscopically examined (per group) for the presence of Leishmania. See further details under Material and Methods. ** Results of two independent groups.

longipalpis/Leishmania chagasi, Lutzomyia migonei/Leishmania amazonensis e Lutzomyia migonei/Leishmania braziliensis, todos eles incriminados na transmissão de leishmaniose cutânea ou visceral. O DNA total a ser amplificado foi extraído de flebotomíneos inteiros, contendo ou não o parasita, sem dissecção prévia do trato digestivo ou combinação de indivíduos. Conteúdos do trato digestivo de flebotomíneos, em especial sangue de camundongo, não interferiram na reação de amplificação. Dez parasitas Leishmania sp. por flebotomíneo foram suficientes para detecção com iniciadores gênero-específicos. Com a utilização de iniciadores para os complexos L. braziliensis e L. mexicana, respectivamente, foi possível discriminar entre L. braziliensis e $L$. amazonensis, em flebotomíneos infectados experimentalmente $(L$. migonei).

\section{ACKNOWLEDGEMENTS}

We wish to thank Márcio Sobreira for technical assistance, the Conselho Nacional de Desenvolvimento Científico e Tecnológico (CNPq) and Fundação de Amparo à Pesquisa de Minas Gerais (FAPEMIG) for financial support and the PIBIC fellowship provided to one of us (E.M. Michalsky, undergraduated student).

\section{REFERENCES}

1. ARANSAY, A.M.; SCOULICA, E. \& TSELENTIS, Y. - Detection and identification of Leishmania DNA within naturally infected sand flies by seminested PCR on minicircle kinetoplastic DNA. Appl. Environ. Microbiol., 66: 1933-1938, 2000.
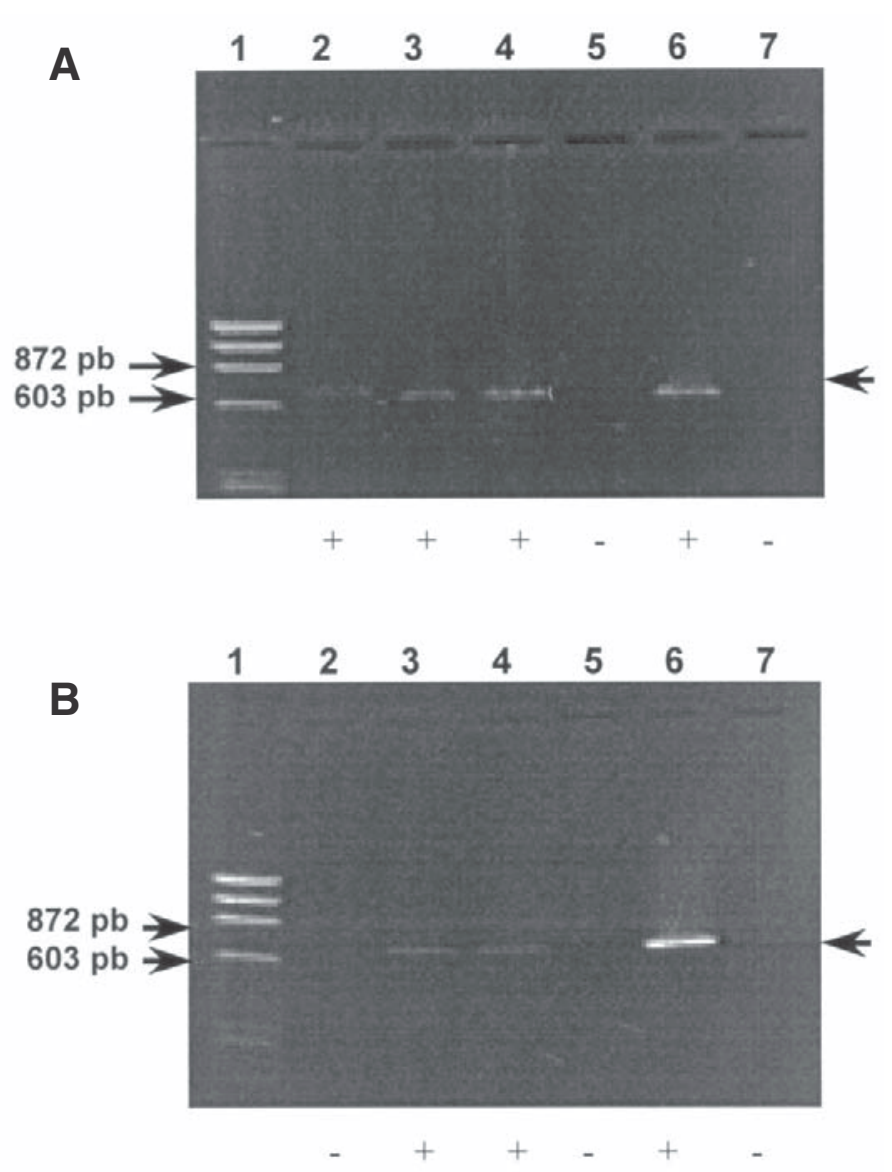

Fig. 2 - Electrophoresis profile on 1\% agarose gels of PCR products after DNA amplification of test samples with complex-specific primers. A. DNA from Leishmania infected sandflies. 1- ФX174RF/HaeIII DNA marker; 2- Positive control (L. braziliensis DNA); 3 to 6- L. migonei after feeding in mouse blood infected with $L$. braziliensis. 7- Negative control. B. DNA from Leishmania infected sandflies. 1-ФX174RF/HaeIII DNA marker; 2 to 5- L. migonei after feeding in mouse blood infected with L. amazonensis; 6- Positive control (L. amazonensis DNA); 7- Negative control. The arrow on the right side of both figures indicates the 700 to 800-bp DNA fragment. Plus (+) or minus (-) at the bottom of the figures indicate the presence or absence of Leishmania in the test samples.

2. ARAÚJO, M.S.S.; SECUNDINO, N.F.C. \& PIMENTA, P.F.P. - Leishmania chagasi: culture of axenic amastigotes at $37^{\circ} \mathrm{C}$. Mem. Inst. Oswaldo Cruz, 94 (suppl. 2): 117,1999

3. AUSUBEL, F.M.; BRENT, R.; KINGSTON, R.E. et al. - Short protocols in molecular biology. 2 ed. New York, John Wiley, 1992.

4. BLANCO, E.E.N. - A biologia do desenvolvimento de Leishmania (Viannia) braziliensis e de Leishmania (Leishmania) amazonensis no flebotomíneo Lutzomyia migonei (Diptera: Psychodidae). Rio de Janeiro, 2000. (Tese de Doutorado - Fundação Oswaldo Cruz).

5. CHANCE, M.L. - The biochemical and immunological taxonomy of Leishmania. In: CHANG, K.P. \& BRAY, R.S. Leishmaniasis. Amsterdam, Elsevier, 1985. p. 93110 .

6. DE BRUIJN, M.H.L. \& BARKER, D.C. - Diagnosis of New World leishmaniasis: specific detection of species of the Leishmania braziliensis complex by amplification of kinetoplast DNA. Acta trop. (Basel), 52: 45-58, 1992. 


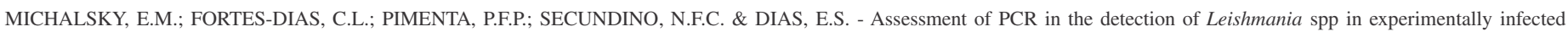
individual phlebotomine sandflies (Diptera: Psychodidae: Phlebotominae). Rev. Inst. Med. trop. S. Paulo, 44(5):255-259, 2002.

7. DEGRAVE, W.; FERNANDEZ, O.; CAMPBELL, B.; BOZZA, M. \& LOPEZ, U.G. Use of molecular probes and PCR for detection and typing of Leishmania: a mini review. Mem. Inst. Oswaldo Cruz, 89: 463-469, 1994.

8. ERESH, S.; McCALLUM, S.M. \& BARKER, D.C. - Identification and diagnosis of Leishmania mexicana complex isolates by polymerase chain reaction. Parasitology, 109: 423-433, 1994.

9. MIRANDA, J.C. - Combinação de captura dirigida e PCR na detecção de flebotomíneos naturalmente infectados por leishmanias. Rio de Janeiro, 1998. (Dissertação de Mestrado - Fundação Oswaldo Cruz).

10. PEREZ, J.E.; OGUSUKU, E.; INGA, R. et al. - Natural leishmania infection of Lutzomyia spp. in Peru. Trans. roy. Soc. trop. Med. Hyg., 88: 161-164, 1994.

11. RODGERS, M.R.; POPPER, S.J. \& WIRTH, D.F. - Amplification of kinetoplast DNA as a tool in the detection and diagnosis of Leishmania. Exp. Parasit., 71: 267-275, 1990.
12. RODRÍGUEZ, N.; AGUILAR, C.M.; BARRIOS, M.A. \& BARKER, D.C. - Detection of Leishmania braziliensis in naturally infected individual sandflies by the polymerase chain reaction. Trans. roy. Soc. trop. Med. Hyg., 93: 47-49, 1999.

13. RODRÍGUEZ, N.; GUZMAN, B.; RODAS, A. et al. - Diagnosis of cutaneous leishmaniasis and species discrimination of parasites by PCR and hybridization. J. clin. Microbiol., 9: 2246- 2252, 1994.

14. SILVA, O.S. \& GRUNEWALD, J. - Contribution to the sand fly fauna (Diptera:Phlebotominae) of Rio Grande do Sul, Brazil, and Leishmania (Viannia) infections. Mem. Inst. Oswaldo Cruz, 94: 579- 582, 1999.

15. TESH, R.B. \& MODI, G.B. - A simple method for experimental infection of phlebotomine sand flies with Leishmania. Amer. J. trop. Med. Hyg., 33: 41-46, 1984.

Received: 26 March 2002

Accepted: 28 June 2002 